\title{
ANALISA POSTUR KERJA KARYAWAN BAGIAN PICK UP DI PT. JALUR NUGRAHA EKAKURIR (JNE) CABANG KAYON, CINERE DENGAN METODE NIOSH
}

\author{
Tedi Dahniar ${ }^{1)}$, Dhiah Budhi Leksonowati ${ }^{1)}$ \\ ${ }^{1}$ Program Studi Teknik Industri, Fakultas Teknik, Universitas Pamulang \\ dosen00924@unpam.ac.id
}

\begin{abstract}
ABSTRAK
Pekerjaan mengangkat merupakan pekerjaan yang memiliki risiko yang tinggi untuk terkena cidera akibat kerja, jika pekerjaan tersebut dilakukan berulang-ulang. Di PT. Jalur Nugraha Ekakurir (JNE) pengangkatan paket adalah salah satu pekerjaan yang dilakukan setiap hari sehingga penulis mengambil risiko ergonomi yang mungkin didapat oleh para karyawan tersebut dengan mengunakan metode NIOSH. Hasil penelitian Lifting Index (LI) pada nomor pengangkatan 1 sebelum perbaikan 3.9 setelah perbaikan menjadi 0.56 , nomor pengangkatan 2 sebelum perbaikan 6.04 setelah perbaikan 0.92 , nomor pengangkatan 3 sebelum pengangkatan 5.07 setelah perbaikan 0.92 sedangkan hasil penelitian Composite Lifting Index (CLI) sebelum perbaikan 7.4 setelah perbaikan 1. Berdasarkan perhitungan Lifting index (LI) melebihi 1 dan Composite Lifting Index (CLI) melebihi 3 sehingga memiliki risiko kerja yang tinggi maka, dilakukan usulan perbaikan postur kerja dan setelah perbaikan postur kerja menghasilkan Lifting index (LI) kurang dari 1 dan Composite lifting Index (CLI) 1 yang berarti pengangkatan paket aman untuk dikerjakan.
\end{abstract}

Kata Kunci: Niosh, Pekerjaan Mengangkat, Lifting Index, Composite Lifting Index,

\section{I.PENDAHULUAN}

Pekerjaan mengangkat merupakan pekerjaan yang memiliki risiko yang tinggi untuk terkena cidera akibat kerja, jika pekerjaan tersebut dilakukan berulang-ulang. Di PT. Jalur Nugraha Ekakurir (JNE) pengangkatan paket adalah salah satu pekerjaan yang dilakukan setiap hari sehingga penulis mengambil risiko ergonomi yang mungkin didapat oleh para karyawan tersebut dengan mengunakan metode NIOSH.

Postur kerja karyawan adalah duduk, jongkok, bungkuk dan berdiri. Keluhan rasa sakit pada bagian tubuh sudah dirasakan oleh para karyawan akibat postur kerja yang tidak alami, berupa rasa sakit pada leher, bahu, punggung, pinggang dan pergelangan tangan. Salah satu upaya yang dapat dilakukan untuk mengatasi hal ini adalah memperbaiki metode kerja yaitu postur kerja yang tidak ergonomis.

Berikut ini adalah data tingkat kelelahan karyawan JNE dari tahun 2015 - 2017 dapat dilihat pada Tabel 1.

Tabel 1 Data Tingkat Kelelahan Karyawan JNE

\begin{tabular}{|c|c|c|c|c|c|c|c|c|}
\hline \multirow{2}{*}{ Tahun } & \multicolumn{7}{|c|}{ Tingkat Kelelahan } \\
\cline { 2 - 9 } & \multicolumn{2}{|c|}{ A } & \multicolumn{2}{|c|}{ B } & \multicolumn{2}{c|}{ C } & \multicolumn{2}{c|}{ D } \\
\cline { 2 - 9 } & Aktual & $\%$ & Aktual & \% & Aktual & \% & Aktual & \% \\
\hline $\mathbf{2 0 1 5}$ & 62 & 55.36 & 26 & 23.21 & 24 & 21.43 & - & - \\
\hline $\mathbf{2 0 1 6}$ & 32 & 28.57 & 39 & 34.82 & 37 & 33.04 & 4 & 3.57 \\
\hline $\mathbf{2 0 1 7}$ & 29 & 25.89 & 37 & 33.06 & 41 & 36.61 & 5 & 4.46 \\
\hline
\end{tabular}

(sumber: bagian dari hasil penelitian 2018)

Berdasarkan Tabel 1 di atas mengenai keluhan karyawan JNE pada 3 tahun terakhir. Data menunjukan keluhan rasa sakit yang dirasakan oleh karyawan bagian pick up. Terjadi peningkatan kelelahan pada setiap tahunnya yang menandakan bahwa sikap kerja karyawan di PT. Jalur Nugraha Ekakurir (JNE) bermasalah. Pada tabel terdapat keterangan Tingkat Kelelahan A, B, C dan D. hal ini menjelaskan Tingkat Kelelahan $\mathrm{A}=$ tidak sakit, Tingkat Kelelahan $\mathrm{B}=$ agak sakit, Tingkat Kelelahan $\mathrm{C}=$ sakit dan Tingkat Kelelahan D = sakit sekali. 


\section{II.DASAR TEORI}

\section{A.Ergonomi}

Menurut International Labour Organization (ILO), ergonomi adalah penerapan ilmu biologi manusia sejalan dengan ilmu rekayasa demi tercapainya penyesuaian bersama antara pekerjaan dan manusia secara optimum yang bertujuan supaya bermanfaat demi efisiensi dan kesejahteraan. Ergonomi adalaha ilmu yang menemukan dan mengumpulkan informasi mengenai tingkah laku, kemampuan, keterbatasan dan karakteristik manusia dalam perancangan mesin, peralatan, sistem kerja, dan lingkungan yang produktif, nyaman, aman dan efektif bagi manusia. Ergonomi merupakan cabang ilmu yang teratur atau sistematis untuk memanfaatkan informasi tentang sifat manusia, kemampuan manusia dan keterbatasannya dalam merancang suatu sistem kerja yang baik supaya tujuan bisa dicapai secara efektif, nyaman dan aman (dikutip oleh: Wowo Sunaryo Kuswana, 2017).

\section{B.Postur Kerja}

Postur Kerja dalam penelitian ini adalah sikap atau posisi tubuh responden (leher, batang tubuh, lengan atas, lengan bawah, pergelangan tangan, dan kaki) memiliki sudut ekstrim dari posisi normal, yaitu sejajar dengan batang tubuh saat melakukan aktivitas kerja (Abdul Rahman, 2017).

Kriteria Objektif:

1. Risiko sangat rendah:

Bila total skor postur tubuh responden diperoleh skor sebesar 1 berdasarkan Rappid Entire Body Assestmen.

2. Risiko rendah:

Bila total skor postur tubuh responden diperoleh skor sebesar $2-3$ berdasarkan Rappid Entire Body Assest men.

3. Risiko sedang:

Bila total skor dari postur tubuh responden diperoleh skor sebesar 4-7 berdasarkan Rappid Entire Body Assestmen.

4. Risiko Tinggi:

Bila total skor dari postur tubuh resp onden diperoleh skor sebesar $8-10$ berdasarkan Rappid Entire Body Assestmen.

5. Risiko Sangat Tinggi:
Bila total skor dari postur tubuh responden diperoleh skor sebesar $11-15$ berdasarkan Rappid Entire Body Assestmen.

\section{Manual Material Handling}

Definisi Manual Material Handling (MMH) adalah komponen dari berbagai pekerjaan dan kegiatan yang dilakukan dalam hidup. Biasanya melibatkan mengangkat, menurunkan, mendorong, menarik dan membawa benda dengan tangan. Tugas ini memiliki kesamaan yang berpotensi menghasilkan beberapa efek yang merugikan kesehatan, dari luka sederhana, memar, nyeri otot dan kondisi serius yang berkaitan dengan nyeri pinggang (Septina Dwi A.P, 2010).

\section{C.Tinjauan Postur Kerja Sabagai Faktor Risiko Ergonomi Musculuskeletal Disorders (MSDs)}

Musculoskeletal disorders (MSDs) adalah cedera atau gangguan otot, saraf, tendon, sendi, kartilago, sistem saraf, dan struktur penunjang seperti discus invertebral yang diperburuk oleh kegiatan fisik yang terlalu lama seperti gerakan pengulangan, beban, getaran, atau postur janggal (NIOSH, 1997) (dikutip oleh: Annisa Septiani, 2017).

Peter Vi (2000) menjelaskan bahwa, terdapat beberapa faktor yang dapat menyebabkan terjadinya keluhan otot skeletal, yaitu (dikutip oleh: Yulien Lovenny E.G, 2017):

1. Peregangan otot yang berlebihan

2. Aktivitas berulang

3. Sikap kerja tidak alamiah

\section{National for Occupational Safety and Health (NIOSH)}

NIOSH Lifting Index pertama kali diperkenalkan oleh NIOSH untuk aktivitas pekerjaan lifting/mengangkat. NIOSH merekomendasikan metode sederhana untuk mengukur kemungkinan terjadinya pembebanan otot yang berlebihan atas dasar karakteristik pekerjaan. (Tarwaka, 2004 dalam Krishna dkk, 2017). NIOSH (National for Occupational Safety and Health) adalah suatu institusi yang menangani hal-hal yang terkait permasalahan keselamatan dan kesehatan kerja di Amerika serikat (Krishna dkk, 2017).

\section{Kerangka Fikir}




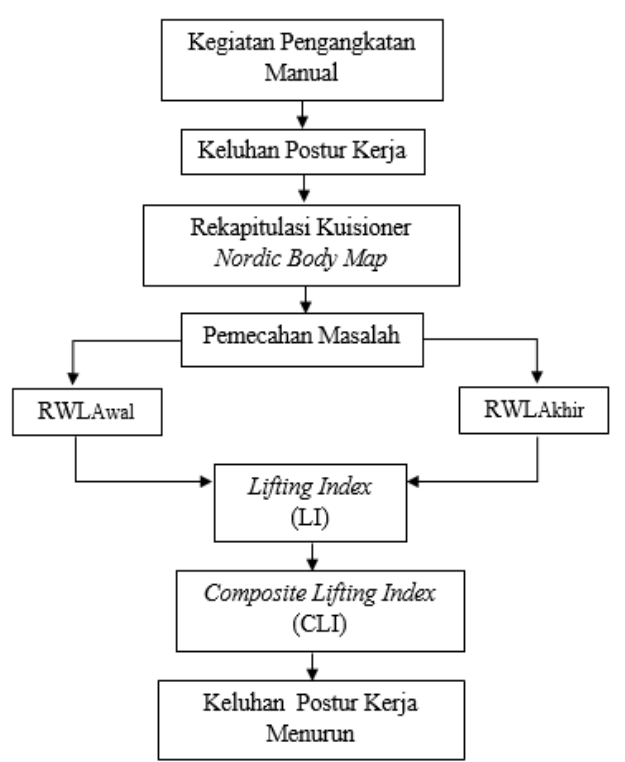

(Sumber: Bagian Dari Hasil Penelitian, 2018) Gambar 1 Kerangka Fikir

\section{III.METODOLOGI PENELITIAN}

Metode analisis data dalam penelitian ini adalah sebagai berikut:

1. Hasil Data Standard Nordic Questionnaire

2. Menghitung Recommended Weight Limit (RWL)

$\mathrm{RWL}=\mathrm{LC} \times \mathrm{HM} \times \mathrm{VM} \times \mathrm{DM} \times \mathrm{AM} \times \mathrm{FM} \times \mathrm{CM}$

3. Menghitung Lifting Index (LI)

$$
L I=\frac{\text { Bobot Beban Aktual }}{\text { Min (RWL awal, RWL akhir })}
$$

4. Menghitung Composite Lifting Index (CLI)

$$
\begin{aligned}
C L I= & S T L I 1+F I L I 2\left(\left(\frac{1}{F M 1,2}\right)-\left(\frac{1}{F M 1}\right)\right) \\
& + \text { FILI3 }\left(\left(\frac{1}{F M 1,2,3}\right)-\left(\frac{1}{F M 1,2}\right)\right)
\end{aligned}
$$

5. Hasil Analisa Postur Kerja

6. Usulan Perbaikan Postur Kerja

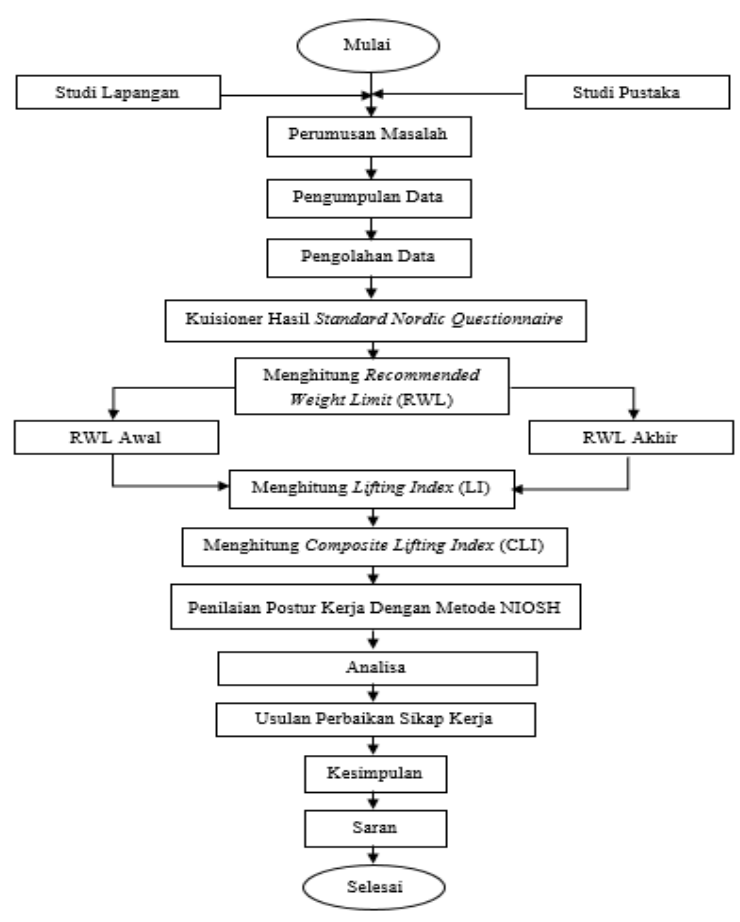

\section{Flowchart Metode Penelitian}

Berikut Flow Chart dari penelitian ini dapat dilihat pada Gambar 3

(Sumber: Pengolahan Data dari Berbagai Sumber) Gambar 2 Flow Chart Metodologi Penelitian

\section{IV.HASIL DAN PEMBAHASAN}

Teknik pengambilan data dilakukan melalui kegiatan pengamatan langsung dimana karyawan di PT. Jalur Nugraha Ekakurir (JNE) bagian pick up menjadi objek penelitian melakukan semua kegiatan pengangkatan paket secara manual dengan diawali pengangkatan paket dari dalam counter JNE kemudian diangkat keatas mobil pick up. Pengolahan data dilakukan dengan menggunakan metode NIOSH Lifting Equation.

\section{Data Postur Kerja}

Dibawah ini salah satu dari tiga nomor pengangkatan paket dapat dilihat beberapa aktivitas yang dilakukan karyawan JNE saat hendak melakukan proses pick up diantaranya karyawan melakukan pengangkatan paket dari dalam counter JNE kemudian membawanya menuju mobil pick up .

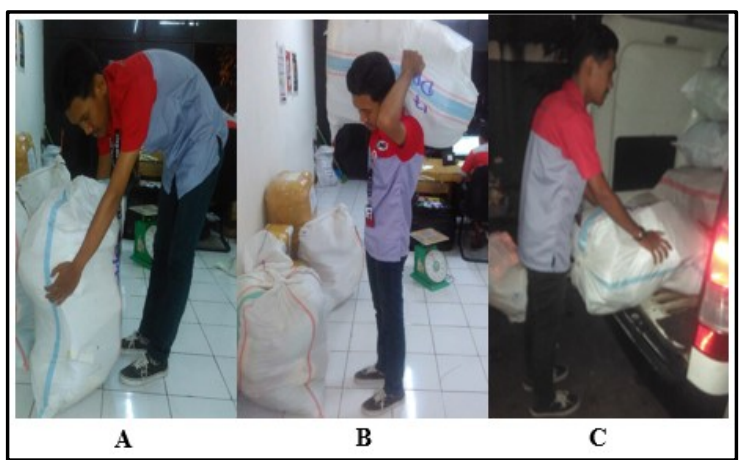

(Sumber: PT. Jalur Nugraha Ekakurir (JNE))

Gambar 4 Posisi karyawan saat pengangkatan paket. A. Awal Pengangkatan Paket. B. Saat Mengangkat Paket. C. Saat Penurunan Paket

\section{Hasil Penelitian Berat Beban}

Berat beban paket yang diangkat karyawan dapat dilihat pada Table 2.

Tabel 2 Berat Beban Paket

\begin{tabular}{|c|c|}
\hline Nomor Pengangkatan & Berat Beban (Kg) \\
\hline Nomor Pengangkatan 1 & 20 \\
\hline Nomor Pengangkatan 2 & 29 \\
\hline Nomor Pengangkatan 3 & 29 \\
\hline
\end{tabular}

(Sumber: Bagian Dari Hasil Penelitian, 2018) 
Faktor Menentukan Besaran Recommended Weight Limit (RWL)

RWL dihitung berdasarkan enam variabel seperti yang terlihat pada Gambar 5 (Tarwaka, 2004).

(Sumber: Waters and Anderson, 1996)

Gambar 5 Ilustrasi posisi tangan pada saat mengangkat beban dan sudut putar pada saat memindahkan beban.

\section{Horizontal Multiplier (HM)}

Dengan $\mathrm{H}$ adalah jarak horizontal yang didefinisikan sebagai jarak antara titik tengah pergelangan kaki bagian dalam sampai hingga titik yang diproyeksikan dari titik pusat beban saat pengangkatan. Besaran HM ditentukan dengan rumus:

$$
\begin{aligned}
& H M=\frac{25}{H} \\
& H M=\frac{25}{30}=0.83
\end{aligned}
$$

Berikut rekapitulasi perhitungan seperti pada Tabel 4.

Tabel 3 Rekapitulasi Perhitungan Horizontal Multiplier (HM)

(Sumber: Bagian Dari Hasil Penelitian, 2018)

\section{Vertical Multiplier (VM)}

Dengan $\mathrm{V}$ didefinisikan sebagai jarak dari lantai terhadap posisi kedua tangan saat diangkat, yang biasanya dianggap sebagai titik tengah dari objek yang dibawa. Besaran VM ditentukan dengan rumus:

$$
\begin{aligned}
& V M=1-(0,003|V-75|) \\
& V M=1-(0,003|40-75|)=0,89
\end{aligned}
$$

Berikut rekapitulasi perjitungan seperti pada Tabel 4.

Tabel 4 Rekapitulasi Perhitungan Vertical Multiplier (VM)

\begin{tabular}{|l|c|c|c|c|}
\hline Nomor Pengangkatan & $\begin{array}{c}\text { Vorigin } \\
\text { (centimeter) }\end{array}$ & $\begin{array}{c}\text { V destination } \\
\text { (centimeter) }\end{array}$ & $\begin{array}{c}\text { VMorigin } \\
\text { (konversi niosh) }\end{array}$ & $\begin{array}{c}\text { V destination } \\
\text { (konversi niosh) }\end{array}$ \\
\hline Nomor Pengangkat 1 & 40 & 80 & 0.89 & 0.98 \\
\hline Nomor Pengangkat 2 & 35 & 90 & 0.88 & 0.95 \\
\hline Nomor Pengangkat 3 & 35 & 90 & 0.88 & 0.95 \\
\hline
\end{tabular}

(Sumber: Bagian Dari Hasil Penelitian, 2018)

\section{Asymmetric Multiplier (AM)}

Dimana A adalah sudut asimetrik yang merupakan sudut yang terbentuk antara pertengahan bidang sagital dan garis asimetri. Bidang sagital adalah bidang yang membagi tubuh menjadi dua bagian, kanan dan kiri ketika posisi tubuh netral (tidak ada rotasi bahu dan kaki). Besaran AM ditentukan dengan rumus:

$$
\begin{aligned}
& A M=1-0,0032 . A \\
& A M=1-0,0032 \cdot 0=1
\end{aligned}
$$

Berikut rekapitulasi perhitungan seperti pada Tabel 5.

Tabel 5 Rekapitulasi Perhitungan Asymmetric Multiplier (AM)

\begin{tabular}{|c|c|c|c|c|}
\hline $\begin{array}{c}\text { Nomor } \\
\text { Pengangkatan }\end{array}$ & $\begin{array}{c}\text { A origin } \\
\text { (derajat) }\end{array}$ & $\begin{array}{c}\text { A destination } \\
\text { (derajat) }\end{array}$ & $\begin{array}{c}\text { AM origin } \\
\text { (konversi niosh) }\end{array}$ & $\begin{array}{c}\text { A destination } \\
\text { (konversi niosh) }\end{array}$ \\
\hline Nomor Pengangkat 1 & 0 & 90 & 1 & 0.71 \\
\hline Nomor Pengangkat 2 & 0 & 90 & 1 & 0.71 \\
\hline Nomor Pengangkat 3 & 0 & 90 & 1 & 0.71 \\
\hline
\end{tabular}

(Sumber: Bagian Dari Hasil Penelitian, 2018)

\section{Distance Multiplier (DM)}

Dengan D didefinisikan sebagai jarak perbedaan/perpindahan secara vertikal antara posisi awal dan akhir dari pengangkatan. Besaran DM ditentukan dengan rumus:

$$
\begin{aligned}
& D M=0,82+\frac{4,5}{D} \\
& D M=0,82+\frac{4,5}{40}=0,93
\end{aligned}
$$

Berikut rekapitulasi perhitungan seperti pada Tabel 6.

Tabel 6 Rekapitulasi Perhitungan Distance Multiplier (DM)

\begin{tabular}{|c|c|c|}
\hline Nomor Pengangkatan & $\begin{array}{c}\text { D } \\
\text { (Centi } \\
\text { meter) }\end{array}$ & $\begin{array}{c}\text { Dm } \\
\text { (Kon } \\
\text { versi } \\
\text { Nios } \\
\text { h) }\end{array}$ \\
\hline Nomor Pengangkatan 1 & 40 & 0.93 \\
\hline Nomor Pengangkatan 2 & 55 & 0.9 \\
\hline
\end{tabular}




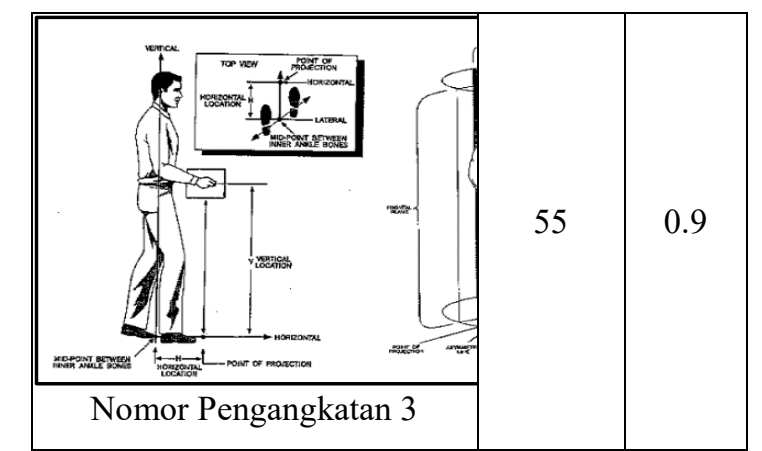

(Sumber: Bagian Dari Hasil Penelitian, 2018) Coupling Multiplier (CM)

Faktor pengali pegangan atau Coupling Multiplier (CM) ditentukan dari tabel Coupling Multiplier (CM). Coupling Multiplier (CM) ditentukan oleh kondisi pegangan (Handle) benda yang diangkat dan juga nilai $\mathrm{V}$. Paket yang diangkat masuk kedalam kriteria Poor karena paket tidak mempunyai pegangan dan tangan tidak dapat meraih dengan mudah. Sama halnya dengan

FM, faktor pengali pegangan atau Coupling Multiplier (CM) ditentukan dari tabel. CM ditentukan oleh kondisi pegangan (Handle) benda yang diangkat dan juga nilai $\mathrm{V}$. Unt uk Coupling Multiplier adalah (Waters dkk,

1993 dalam Taufik Hidayatullah, 2018):

a. Kriteria Good adalah:

1) Kontainer atau box merupakan disain optimal, pegangan bahannya tidak licin.

2) Benda yang didalamnya tidak mudah tumpah.

3) Tangan dapat dengan nyaman meraih box tersebut.

b. Kriteria Fair adalah:

1) Kontainer atau box tidak mempunyai pegangan.

2) Tangan tidak dapat meraih dengan mudah.

c. Kriteria Poor adalah:

1) Box tidak mempunyai handle/ pegangan.

2) Sulit dipegang (Licin, Tajam, dll).

3) Berisi barang yang tidak stabil, (Pecah, Jatuh, Tumpah, dll)

4) Memerlukan sarung tangan untuk mengangkatnya.

Berikut dibawah ini Coupling Multiplier seperti pada Tabel 7.
Tabel 7 Coupling Multiplier

\begin{tabular}{|c|c|c|}
\hline Coupling & $\begin{array}{c}\mathrm{V}<75 \\
\mathbf{c m}(30 \text { in })\end{array}$ & $\begin{array}{c}\mathrm{V}>75 \\
\mathbf{c m}(30 \\
\text { in) }\end{array}$ \\
\hline Good & 1 & 1 \\
\hline Fair & 0,95 & 1 \\
\hline Poor & 0,90 & 0,90 \\
\hline
\end{tabular}

(Sumber: Waters dkk, 1993)

Hasil Coupling Multiplier dapat dilihat pada Tabel 8.

\begin{tabular}{|c|c|c|c|c|}
\hline Nomor Pengangkatan & $\begin{array}{c}\text { Horiginal } \\
\text { (centimeter) }\end{array}$ & $\begin{array}{c}\text { H destination } \\
\text { (centimeter) }\end{array}$ & $\begin{array}{c}\text { HM original } \\
\text { (konversi NIOSH) }\end{array}$ & $\begin{array}{c}\text { HM destination } \\
\text { (konversi NIOSH) }\end{array}$ \\
\hline Nomor Pengangkatan 1 & 30 & 60 & 0.83 & 0.42 \\
\hline Nomor Pengangkatan 2 & 35 & 60 & 0.71 & 0.42 \\
\hline Nomor Pengangkatan 3 & 20 & 50 & 1.25 & 0.5 \\
\hline
\end{tabular}

Tabel 8 Coupling Multiplier Pengangkatan Paket

\begin{tabular}{|c|c|c|}
\hline $\begin{array}{c}\text { Nomor } \\
\text { Pengangkatan }\end{array}$ & $\begin{array}{c}\text { Coupling } \\
\text { Type Fair }\end{array}$ & $\begin{array}{c}\text { Coupling } \\
\text { Multiplier } \\
\text { (CM) }\end{array}$ \\
\hline $\begin{array}{c}\text { Nomor } \\
\text { Pengangkatan } \\
1\end{array}$ & $\mathrm{~V}>75$ & 0.90 \\
\hline $\begin{array}{c}\text { Nomor } \\
\text { Pengangkatan } \\
2\end{array}$ & $\mathrm{~V}>75$ & 0.90 \\
\hline $\begin{array}{c}\text { Nomor } \\
\text { Pengangkatan } \\
3\end{array}$ & $\mathrm{~V}>75$ & 0.90 \\
\hline
\end{tabular}

(Sumber: Bagian Dari Hasil Penelitian, 2018)

\section{Frequency Multiplier (FM)}

Berbeda dengan faktor-

faktor pengali yang telah dibahas terdahulu, FM tidak dihitung secara rumus matematis, namun dapat ditentukan berdasarkan tabel acuan. Dalam hal ini, FM ditentukan oleh $f$ rekuensi rata-rata pengangkatan per menit 
dan posisi beban saat diangkat dari lantai. $\mathrm{F}$ requency Multiplier seperti pada Tabel 9.

Tabel 9 Frequency Multiplier

\begin{tabular}{|c|c|c|c|c|c|c|}
\hline \multirow{3}{*}{$\begin{array}{c}\text { Frekunsi } \\
\text { Pengangkatan/menit }\end{array}$} & \multicolumn{6}{|c|}{ Durasi Kerja } \\
\hline & \multicolumn{2}{|c|}{$<1 \mathrm{Jam}$} & \multicolumn{2}{|c|}{$<2 \mathrm{Jam}$} & \multicolumn{2}{|c|}{$<3$ jam } \\
\hline & $\begin{array}{l}\mathrm{V}< \\
75 \\
\mathrm{~cm}\end{array}$ & $\begin{array}{l}\mathrm{V}> \\
75 \\
\mathrm{~cm}\end{array}$ & $\begin{array}{l}\mathrm{V}< \\
75 \\
\mathrm{~cm}\end{array}$ & $\begin{array}{l}\mathrm{V}> \\
75 \\
\mathrm{~cm} \\
\end{array}$ & $\begin{array}{l}\mathrm{V}< \\
75 \\
\mathrm{~cm}\end{array}$ & $\begin{array}{l}\mathrm{V}> \\
75 \\
\mathrm{~cm}\end{array}$ \\
\hline 0,2 & 1 & 1 & 0,95 & 0,95 & 0,85 & 0,85 \\
\hline 1,5 & 0,97 & 0,97 & 0,92 & 0,92 & 0,81 & 0,81 \\
\hline 1 & 0,94 & 0,94 & 0,88 & 0,88 & 0,75 & 0,75 \\
\hline 2 & 0,91 & 0,91 & 0,84 & 0,84 & 0,65 & 0,65 \\
\hline 3 & 0,88 & 0,88 & 0,79 & 0,79 & 0,55 & 0,55 \\
\hline 4 & 0,84 & 0,84 & 0,72 & 0,72 & 0,45 & 0,45 \\
\hline 5 & 0,80 & 0,80 & 0,60 & 0,60 & 0,35 & 0,35 \\
\hline 6 & 0,75 & 0,75 & 0,50 & 0,50 & 0,27 & 0,27 \\
\hline 7 & 0,70 & 0,70 & 0,42 & 0,42 & 0,22 & 0,22 \\
\hline 8 & 0,60 & 0,60 & 0,35 & 0,35 & 0,18 & 0,18 \\
\hline 9 & 0,52 & 0,52 & 0,30 & 0,30 & 0 & 0,15 \\
\hline 10 & 0,45 & 0,45 & 0,26 & 0,26 & 0 & 0,13 \\
\hline 11 & 0,41 & 0,41 & 0 & 0,23 & 0 & 0 \\
\hline 12 & 0,37 & 0,37 & 0 & 0,21 & 0 & 0 \\
\hline 13 & 0 & 0,34 & 0 & 0 & 0 & 0 \\
\hline 14 & 0 & 0,31 & 0 & 0 & 0 & 0 \\
\hline 15 & 0 & 0,28 & 0 & 0 & 0 & 0 \\
\hline$>15$ & 0 & 0 & 0 & 0 & 0 & 0 \\
\hline
\end{tabular}

(Sumber: Bagian Dari Hasil Penelitian, 2018)

Hasil Frekuensi Multiplier dapat dilihat pada Tabel 10.

Tabel 10 Frequency Multiplier Pengangkatan Paket

\begin{tabular}{|l|c|}
\hline Nomor Pengangkatan & Frequency Multiplier (FM) \\
\hline Nomor Pengangkatan 1 & 0.91 \\
\hline Nomor Pengangkatan 2 & 0.91 \\
\hline Nomor Pengangkatan 3 & 0.91 \\
\hline
\end{tabular}

(Sumber: Bagian Dari Hasil Penelitian, 2018)

\section{Pengolahan Data RWL/LI}

Perhitungan RWL/LI ditentukan dengan rumus:

Dapat dilihat bahwa RWLAwal > RWLAkhir , sehingga RWLAkhir yang dijadikan sebagai acuan dalam perhitungan Lifting Index.

$$
\mathrm{LI}=\frac{20 \mathrm{~kg}}{5.12 \mathrm{~kg}}=3.9
$$

Karena LI > 3, maka dapat disimpulkan bahwa pada nomor pengangkatan 1 berisiko untuk dikerjakan. Berikut rekapitulasi perhitungan RWL/LIseperti pada Tabel 11.

Tabel 11 Rekapitulasi perhitungan RWL/LI

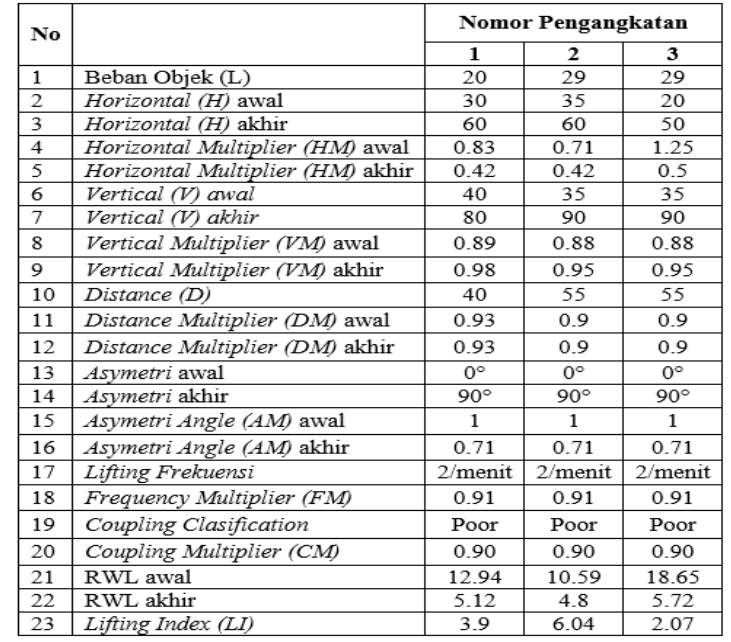

(Sumber: Bagian Dari Hasil Penelitian, 2018)

\section{Hasil Penelitian Akhir Variabel NIOSH Lifting Equation Pada Pengangkatan Paket}

a. Frequency Independent Recommended Weight Limit (FIRWL)

FIRWL adalah berat beban yang dianjurkan tanpa menghitungkan durasi dan frekuensi pengangkatan. Besaran FIRWL ditentukan dengan rumus:
FIRWL = LC $\times$ HM $\times$ VM $\times$ DM $\times$ AM $\mathrm{x} \mathrm{CM}$

FIRWL $=23 \times 0.42 \times 0.98 \times 0.93 \times 0.71$ $\mathrm{x} 0.90$

FIRWL $=5.62$

b. Single Task Recommended Weight Limit (STRWL)

STRWL adalah beban yang direkomendasikan dalam satu kali tugas pengangkatan. Besaran STRWL ditentukan dengan rumus:

$$
\begin{aligned}
\text { STRWL }= & \text { LC } \times \text { HM } \times \text { VM } \times \text { DM } \times \text { AM } \\
& \times \text { CM } \times \text { FM } \\
\text { STRWL }= & 23 \times 0.42 \times 0.98 \times 0.93 \times 0.71 \\
\text { STRWL }= & 5.12
\end{aligned}
$$

$$
\begin{aligned}
\mathrm{RWL} \text { Awal }= & \mathrm{LC} \times \mathrm{HM} \times \mathrm{VM} \times \mathrm{DM} \times \\
& \mathrm{AM} \times \mathrm{FM} \times \mathrm{CM} \\
= & 23 \times 0.83 \times 0,89 \times 0,93 \\
& \times 1 \times 0,91 \times 0.90 \\
= & 12,94 \mathrm{~kg} \\
\mathrm{RWL} \text { Akhir }= & \mathrm{LC} \times \mathrm{HM} \times \mathrm{VM} \times \mathrm{DM} \times \\
& \mathrm{AM} \times \mathrm{FM} \times \mathrm{CM} \\
= & 23 \times 0,42 \times 0,98 \times 0.93 \times \\
= & 0,71 \times 0,91 \times 0,90 \\
= & 5,12 \mathrm{~kg}
\end{aligned}
$$


c. Frequency Independent Lifting Index (FILI) FILI merupakan indeks risiko satu kali pengangkatan tanpa memperhitungkan frequensi. Besaran FILI ditentukan dengan rumus:

$F I L I=\frac{L \max }{F I R W L}=\frac{29}{5.62}=5.16$

d. Single Task Lifting Indeks (STLI)

STLI merupakan indeks risiko untuk satu kali pengangkatan tanpa memperhitungkan frekuensi.

$S T L I=\frac{\operatorname{Lavg}}{S T R W L}=\frac{26}{5.12}=5.08$

Hasil pengukuran variabel-variabel sebelumnya diatas dilakukan perhitungan dengan menggunakan rumusan dari Niosh Lifting equation, untuk mengetahui indeks risiko pengangkatan masing-masing (STLI), didapat hasil sebagai berikut:

Tabel 12 Hasil Akhir Perhitungan Variabel Niosh Lifting Equation Pengangkatan Paket

\begin{tabular}{|c|c|c|c|}
\hline \multirow{2}{*}{ Variabel } & \multicolumn{3}{|c|}{$\begin{array}{c}\text { Pekerjaan } \\
\text { Pengangkatan Paket }\end{array}$} \\
\hline & 1 & 2 & 3 \\
\hline $\mathrm{HM}$ & 0.42 & 0.42 & 0.5 \\
\hline VM & 0.98 & 0.95 & 0.95 \\
\hline DM & 0.93 & 0.9 & 0.9 \\
\hline AM & 0.71 & 0.71 & 0.71 \\
\hline $\mathrm{CM}$ & 0.90 & 0.90 & 0.90 \\
\hline \multirow{2}{*}{ Variabel } & \multicolumn{3}{|c|}{$\begin{array}{c}\text { Pekerjaan } \\
\text { Pengangkatan Paket }\end{array}$} \\
\hline & 1 & 2 & 3 \\
\hline FIRWL & 5.62 & 5.28 & 6.28 \\
\hline FM & 0.91 & 0.91 & 0.91 \\
\hline STRWL & 5.12 & 4.8 & 5.72 \\
\hline FILI & 10.5 & 5.49 & 4.62 \\
\hline
\end{tabular}

\begin{tabular}{|l|c|c|c|}
\hline STLI & 5.08 & 5.42 & 4.54 \\
\hline $\begin{array}{l}\text { New Task } \\
\text { Number }\end{array}$ & 2 & 1 & 3 \\
\hline
\end{tabular}

(Sumber: Bagian Dari Hasil Penelitian, 2018)

Karena pekerjaan ini termasuk multitasking, maka perhitungan indeks risiko pengangkatan atau Lifting Index (LI) menjadi Composite Lifting Index (CLI) yaitu indeks risiko gabungan ketiga pengangkatan.

$$
\begin{aligned}
\text { CLI }= & \text { STLI1 }+ \text { FILI2 }\left(\left(\frac{1}{\text { FM1,2 }}\right)-\left(\frac{1}{\text { FM1 }}\right)\right) \\
& + \text { FILI3 }\left(\left(\frac{1}{\text { FM1,2,3 }}\right)-\left(\frac{1}{\text { FM1,2 }}\right)\right) \\
\text { CLI }= & 5.42+5.16\left(\left(\frac{1}{(0.91)(0.91)}\right)-\left(\frac{1}{0.91}\right)\right) \\
+ & 4.62\left(\left(\frac{1}{(0.91)(0.91)(0.91)}\right)-\left(\frac{1}{(0.91)(C}\right.\right.
\end{aligned}
$$$$
\mathrm{CLI}=5.42+0.57+0.55=6.54
$$

\begin{tabular}{|c|c|c|c|c|}
\hline Nomor Pengangkatan & $\begin{array}{c}\text { Horiginal } \\
\text { (centimeter) }\end{array}$ & $\begin{array}{c}\text { H destination } \\
\text { (centimeter) }\end{array}$ & $\begin{array}{c}\text { HM original } \\
\text { (konversi NIOSH) }\end{array}$ & $\begin{array}{c}\text { HM destination } \\
\text { (konversi NIOSH) }\end{array}$ \\
\hline Nomor Pengangkatan 1 & 30 & 60 & 0.83 & 0.42 \\
\hline Nomor Pengangkatan 2 & 35 & 60 & 0.71 & 0.42 \\
\hline Nomor Pengangkatan 3 & 20 & 50 & 1.25 & 0.5 \\
\hline
\end{tabular}

CLI $>3$ berarti pengangkatan paket yang dilakukan karyawan JNE ini berisiko dan membutuhkan perbaikan postur kerja segera.

\section{Usulan Perbaikan Postur Kerja}

a. Perbaikan pada beban yang diangkat dengan memodifikasi beban yang diangkat oleh pekerja. Dengan menyediakan hand trolley kemudian untuk mengurangi beban pekerja dengan melakukan team handling yaitu dengan mengangkat beban berdua sehingga beban yang diangkat dapat berkurang karena berat beban akan terbagi.

Dengan melakukan modifikasi ergonomi tersebut maka nilai Indeks Pengangkatan Masing-Masing (STLI) dan Indeks Pengangkatan Gabungan (CLI) dapat turun. Ilustrasi dapat dilihat pada Gambar 7. 


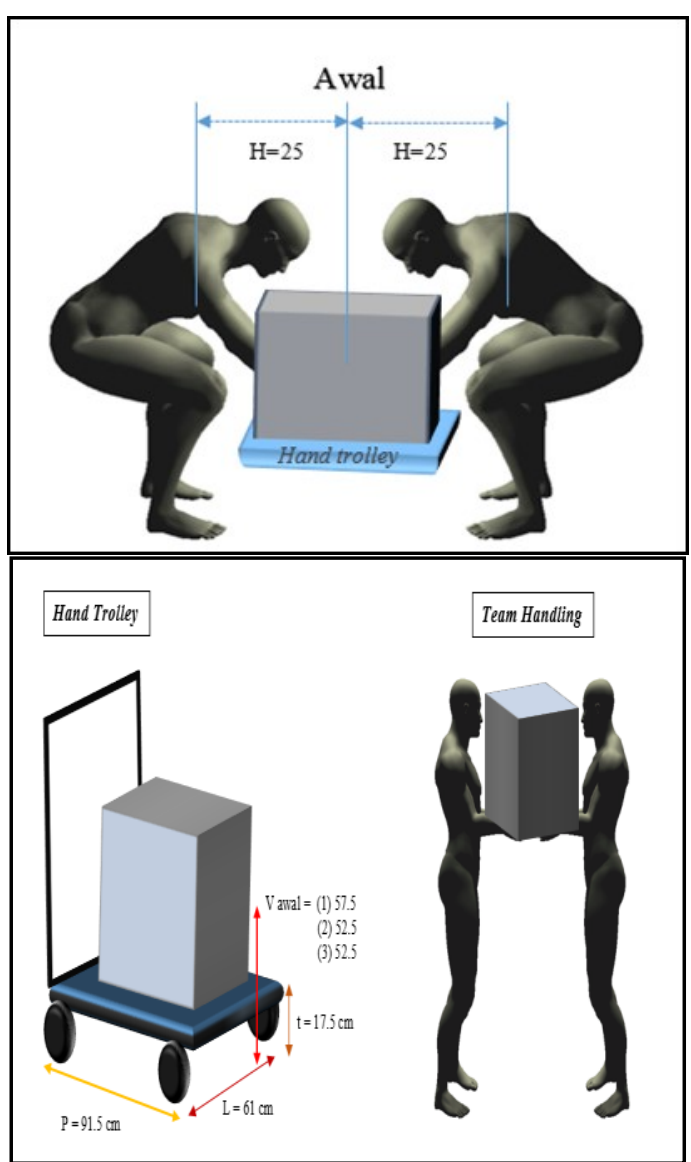

(Sumber: Bagian Dari Hasil Penelitian, 2018) Gambar 7 Ilustrasi Usulan Perbaikan Postur Kerja

b. Perbaikan Jarak Beban Dengan Tubuh (Horizontal multiplier) dengan mendekatkan tubuh dengan beban, pengendalian ini juga tidak akan mengganggu produktivitas dan tidak berhubungan dengan faktor lain. Dengan menjadikan jarak beban dengan tubuh $\mathrm{H}<25 \mathrm{~cm}$ maka nilai perhitungan $\mathrm{NIOSH}$ menjadi $\mathrm{HM}=1.00$, akan tetapi masih dibutuhkan intervensi pada faktor lain supaya indeks risiko pengangkatan menjadi kurang dari 1. Ilustrasi dapat dilihat pada

\section{Gambar 8.}

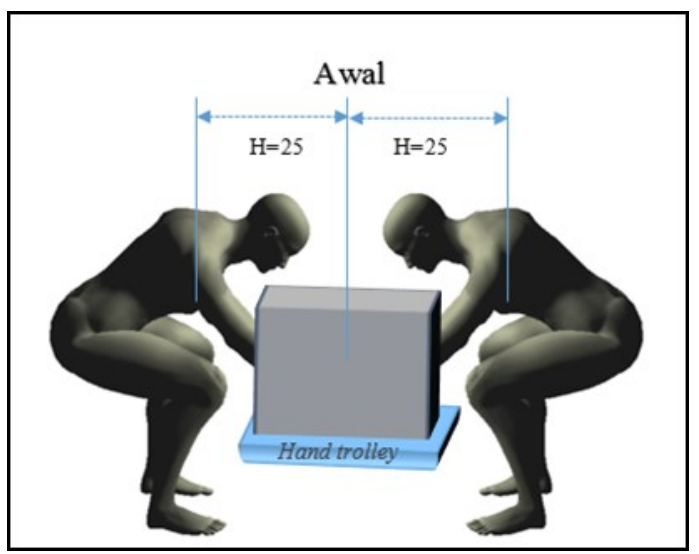

(Sumber: Bagian Dari Hasil Penelitian, 2018)

Gambar 8 Ilustrasi Usulan Perbaikan Postur Kerja

c. Perbaikan Sudut Pengangkatan Antara Pekerja Dengan Posisi Beban (Asymmetric Multiplier) yang dapat dilakukan untuk menghindari terjadinya sudut pengangkatan adalah pekerja harus melakukan pemindahan benda secara benar yaitu tidak hanya menggerakan tulang belakang tetapi seluruh tubuh dalam pengangkatan. Sehingga diharapkan pekerja sebisa mungkin melakukan manual lifting dengan $\mathrm{A}=0^{\circ}$. Ilustrasi dapat dilihat pada Gambar 9.

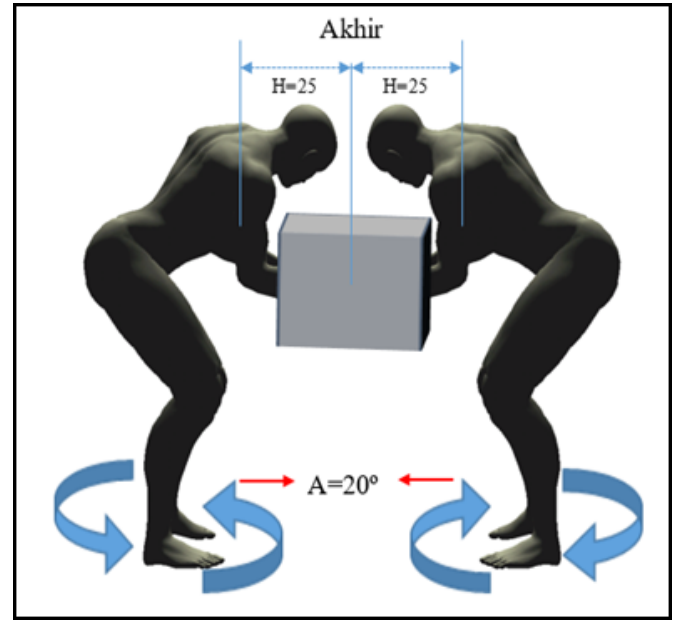

(Sumber: Bagian Dari Hasil Penelitian, 2018) Gambar 9 Ilustrasi Usulan Perbaikan Postur Kerja

d. Menggunakan hand trolley juga dapat memperdekat jarak angkat pada beban sehingga nilai dari Faktor Pengali Pegangan/ Coupling Multiplier (CM) akan berubah. Ilustrasi dapat dilihat pada Gambar 10.

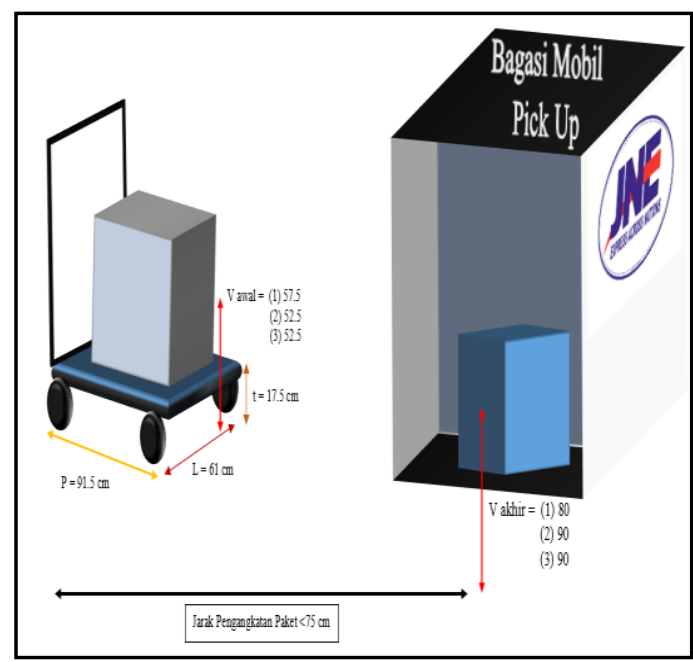

(Sumber: Bagian Dari Hasil Penelitian, 2018) Gambar 10 Ilustrasi Usulan Perbaikan Postur Kerja 


\section{Hasil perhitungan NIOSH setelah perbaikan}

Setelah dilakukan perbaikan yang mungkin bisa dilakukan terkait teknik melakukan pengangkatan yang dapat menurunkan indeks risiko ergonomi yang didapat dari penelitian menggunakan metode NIOSH Lifting Equation.

Perhitungan RWL/LI ditentukan dengan rumus:

$$
\begin{aligned}
\text { RWL Awal }= & \text { LC } \times \text { HM } \times \text { VM x } \\
& \text { DM } \times \text { AM } \times \text { FM x } \\
= & \text { CM } \\
= & 23 \times 1 \times 0,95 \times 1.02 \times \\
= & 18,25 \mathrm{~kg} \\
\text { RWL Akhir }= & \text { LC } \times \text { HM } \times \text { VM x } \\
& \text { DM } \times \text { AM } \times \text { FM x } \\
& \mathrm{CM} \\
= & 23 \times 1 \times 0,98 \times 1.02 \times \\
= & 0,94 \times 0,91 \times 0,90 \\
= & 17,7 \mathrm{~kg}
\end{aligned}
$$

Dapat dilihat bahwa RWLAwal>RWLAkhir , sehingga RWLAkhir yang dijadikan sebagai acuan dalam perhitungan Lifting Index.

$$
\mathrm{LI}=\frac{20 \mathrm{~kg} / 2}{17,7 \mathrm{~kg}}=0,56
$$

Karena LI $<1$, maka setelah perbaikan postur kerja dapat disimpulkan bahwa pada nomor pengangkatan 1 aman untuk dikerjakan.

\begin{tabular}{|c|l|c|c|c|}
\hline \multirow{2}{*}{$N_{0}$} & \multirow{3}{*}{} & \multicolumn{3}{|c|}{ Nomor Pengangkatan } \\
\cline { 3 - 5 } & & 1 & 2 & 3 \\
\hline 1 & Beban Objek (L) & 20 & 29 & 29 \\
\hline 2 & Horizontal (H) awal & 25 & 25 & 25 \\
\hline 3 & Horizontal (H) akhir & 25 & 25 & 25 \\
\hline 4 & Horizontal Multiplier (HM) awal & 1 & 1 & 1 \\
\hline 5 & Horizontal Multiplier (HM) akhir & 1 & 1 & 1 \\
\hline 6 & Vertical (V) awal & 57.5 & 52.5 & 52.5 \\
\hline 7 & Vertical (V) akhir & 80 & 90 & 90 \\
\hline 8 & Vertical Multiplier (VM) awal & 0.95 & 0.93 & 0.93 \\
\hline 9 & Vertical Multiplier (VM) akhir & 0.98 & 0.95 & 0.95 \\
\hline 10 & Distance (D) & 22.5 & 37.5 & 37.5 \\
\hline 11 & Distance Multiplier (DM) akhir & 1.02 & 0.94 & 0.94 \\
\hline 12 & Distance Multiplier (DM) akhir & 1.02 & 0.94 & 0.94 \\
\hline 13 & Asymetri awal & $0^{\circ}$ & $0^{\circ}$ & $0^{\circ}$ \\
\hline 14 & Asymetri akhir & $20^{\circ}$ & $20^{\circ}$ & $20^{\circ}$ \\
\hline 15 & Asymetri Angle (AM) cwal & 1 & 1 & 1 \\
\hline 16 & Asymetri Angle (AM) akhir & 0.94 & 0.94 & 0.94 \\
\hline 17 & Lifting Frekuensi & 2 /menit & 2 /menit & $2 /$ menit \\
\hline 18 & Frequency Multiplier (FM) & 0.91 & 0.91 & 0.91 \\
\hline 19 & Coupling Clasification & Poor & Poor & Poor \\
\hline 20 & Coupling Multiplier (CM) & 0.90 & 0.90 & 0.90 \\
\hline 21 & RWL awal & 18.25 & 16.47 & 16.47 \\
\hline 22 & RWL akhir & 17.7 & 15.81 & 15.81 \\
\hline 23 & Lifting index (LI) & 0.56 & 0.92 & 0.92 \\
\hline
\end{tabular}

Table 13 Rekapitulasi Perhitungan RWL/LI setelah perbaikan

(Sumber: Bagian Dari Hasil Penelitian, 2018)

\section{Hasil Penelitian Akhir Variabel Niosh Lifting Equation Pada Pengangkatan Paket Setelah Perbaikan Postur Kerja}

a. Frequency Independent Recommended Weight Limit (FIRWL)

FIRWL adalah berat beban yang dianjurkan tanpa menghitungkan durasi dan frekuensi pengangkatan. Besaran FIRWL ditentukan dengan rumus:

$$
\begin{aligned}
& \text { FIRWL }=\text { LC } \times \text { HM } \times \text { VM } \times \text { DM } \\
& \mathrm{x} \text { AM x CM } \\
& \text { FIRWL }=23 \times 1 \times 0.98 \times 1.02 \times \\
& 0.94 \times 0.90 \\
& \text { FIRWL }=19.45
\end{aligned}
$$

b. Single Task Recommended Weight Limit (STRWL)

STRWL adalah beban yang direkomendasikan dalam satu kali tugas pengangkatan. Besaran STRWL ditentukan dengan rumus:

$$
\begin{aligned}
\text { STRWL } & \text { LC } \times \text { HM } \times \text { VM } \times \text { DM } x \\
& \text { AM } \times \text { CM } \times \text { FM } \\
\text { STRWL }= & 23 \times 1 \times 0.98 \times 1.02 \times \\
\text { STRWL }= & 0.94 \times 0.90 \times 0.91
\end{aligned}
$$

c. Frequency Independent Lifting Index (FILI) FILI merupakan indeks risiko satu kali pengangkatan tanpa memperhitungkan frequensi. Besaran FILI ditentukan dengan rumus:

$$
F I L I=\frac{\operatorname{Lmax} / 2}{F I R W L}=\frac{29 / 2}{19.45}=0.74
$$

d. Single Task Lifting Indeks (STLI)

STLI merupakan indeks risiko untuk satu kali pengangkatan tanpa memperhitungkan frekuensi.

$$
S T L I=\frac{\operatorname{Lavg} / 2}{S T R W L}=\frac{26 / 2}{17.7}=0.73
$$

Hasil pengukuran variabel-variabel sebelumnya diatas dilakukan perhitungan dengan menggunakan rumusan dari Niosh Lifting equation, untuk mengetahui indeks risiko pengangkatan masing-masing (STLI), didapat hasil sebagai berikut: 
Tabel 10 Hasil Akhir Perhitungan Variabel Niosh Lifting Equation Pengangkatan Paket Setelah Perbaikan

\begin{tabular}{|l|c|c|c|}
\hline \multirow{2}{*}{ Variabel } & \multicolumn{3}{|c|}{ Pekerjaan Pengangkatan } \\
\cline { 2 - 4 } & $\mathbf{1}$ & $\mathbf{2}$ & $\mathbf{3}$ \\
\hline HM & 1 & 1 & 1 \\
\hline VM & 0.98 & 0.94 & 0.94 \\
\hline DM & 1.02 & 0.94 & 0.94 \\
\hline AM & 0.94 & 0.94 & 0.94 \\
\hline CM & 0.90 & 0.90 & 0.90 \\
\hline FIRWL & 19.45 & 17.37 & 17.37 \\
\hline FM & 0.91 & 0.91 & 0.91 \\
\hline STRWL & 17.7 & 15.81 & 15.81 \\
\hline FILI & 0.74 & 0.83 & 0.83 \\
\hline STLI & 0.73 & 0.82 & 0.82 \\
\hline New Task & 3 & 1 & 2 \\
\hline Number & & & \\
\hline
\end{tabular}

(Sumber: Bagian Dari Hasil Penelitian, 2018)

Karena pekerjaan ini termasuk multitasking, maka perhitungan indeks resiko pengangkatan atau lifting indekx (LI) menjadi composite lifting index (CLI) yaitu indeks risiko gabungan ketiga pengangkatan.

$$
\begin{aligned}
& \mathrm{CLI}=\operatorname{STLI} 1+\operatorname{FILI} 2\left(\left(\frac{1}{\mathrm{FM} 1,2}\right)-\left(\frac{1}{\mathrm{FM} 1}\right)\right) \\
& + \text { FILI3 }\left(\left(\frac{1}{\text { FM1,2,3 }}\right)-\left(\frac{1}{\text { FM1,2 }}\right)\right) \\
& \mathrm{CLI}=0.82+0.83\left(\left(\frac{1}{(0.91)(0.91)}\right)-\left(\frac{1}{0.91}\right)\right) \\
& +0.74\left(\left(\frac{1}{(0.91)(0.91)(0.91)}\right)-\left(\frac{1}{(0.91)(1}\right.\right. \\
& \text { CLI }=0.82+0.09+0.09=1
\end{aligned}
$$

\section{V.KESIMPULAN}

Berdasarkan hasil penelitian, pengamatan dan analisa data-data yang telah dilakukan penulis, maka penulis membuat kesimpulan sebagai berikut:

1. Pengangkatan paket di PT. Jalur Nugraha Ekakurir Cabang Kayon, Cinere belum sesuai dengan batasan Recommended Weight Limit (RWL)/Lifting Index (LI). Karena paket pada pengangkatan 1, 2 dan 3 memiliki hasil Lifting Index (LI) yang berbeda yaitu 3.9, 6.04 dan 5.07. Hasil Lifting Index (LI) dari ketiga pengangkatan tersebut menyatakan LI > 3 yang artinya pengangkatan ketiganya berisiko cidera dalam bekerja. Dari data Lifting Index (LI) ketiganya menghasilkan Composite Lifting Index (CLI) sebesar 7.4. Hasil CLI > 3 berarti pengangkatan berisiko dan membutuhkan perbaikan postur kerja segera.

2. Setelah dilakukan perbaikan postur kerja menghasilkan LI $<1$ yang berarti pengangkatan paket yang dilakukan karyawan JNE aman untuk dikerjakan. Indeks pengangkatan gabungan atau Composite Lifting Index (CLI) menghasilkan CLI 1, maka perlu adanya perbaikan dalam melakukan kegiatan tersebut, baik dari sikap kerja maupun dari lingkungan kerja, namun tidak perlu dilakukan dengan sesegera mungkin.

\section{DAFTAR PUSTAKA}

Abdul Rahman, 2017, Analisis Postur Kerja Dan Faktor Yang Berhubungan Dengan Keluhan Musculoskeletal Disorders (Msds) Pada Pekerja Beton Sektor Informal Di Kelurahan Samata Kecamatan Somba Opu Kabupaten Gowa Tahun 2017, Program Studi Kesehatan Masyarakat Fakultas Kedokteran Dan Ilmu Kesehatan Universitas Islam Egeri Alauddin Makassar

Annisa Septiani, 2017, Faktor-Faktor Yang Berhubungan Dengan Keluhan Musculoskeletal Disorders(Msds) Pada Pekerja Bagian Meat Preparation Pt. Bumi Sarimas Indonesia Tahun 2017, Fakultas Kedokteran Dan Ilmu Kesehatan Universitas Islam Negeri Syarif Hidayatullah Jakarta

Krishna Tri Sanjaya, Novi Hendra Wirawan, Baid Adenan, 2017, Analisis Postur Kerja Manual Material Handling Menggunakan Biomekanika dan Niosh, Jurusan Teknik Industri,Universitas PGRI Ronggolawe Tuban

Septina Dwi Ayu Pratiwi, 2010, Analisis Postur Kerja Manual Material 
Handling Menggunakan Metode Rapid Upper Limb Assessment (Rula) Pada Area Produksi 5 Galon Di Pt. Tirta Investama Klaten Jawa Tengah, Fakultas Kedokteran Universitas Sebelas Maret Surakarta

Tarwaka, dkk, 2004, Ergonomi untuk Keselamatan, Kesehatan Kerja dan Produktivitas, Surakarta : Uniba Press.

Taufik Hidayatullah, 2018, Analisa Beban Kerja Manual Material Handling Bagian Hatchery Dengan Metode Owas (Ovako Working Posture Analisis System, Di Pt. Sanbio Laboratories, Fakultas Teknik Universitas Pamulang Tangerang Selatan

Wowo Sunaryo Kuswana, 2017, Ergonomic Dan K3. PT. Remaja Rosdakarya, Bandung 